\title{
The Influence of Liquid Manure on Soybean Yield Characters in the Third Experimental Year
}

\author{
Valeria DEAC ${ }^{1}$, Ioan ROTAR², Roxana VIDICAN², Anamaria MĂLINAȘ²* \\ ${ }^{1}$ Agricultural Research-Development Station Turda \\ 27 Agriculturii Street, Turda, Romania \\ ${ }^{2}$ Faculty of Agriculture, Department of Grassland and Forages Crops, University of Agricultural Sciences and Veterinary Medicine \\ 3-5 Calea Manastur, Cluj-Napoca, Romania \\ "corresponding author, e-mail: ciure_ana@yahoo.com
}

Bulletin USAMV series Agriculture 75(1)/2018

Print ISSN 1843-5246; Electronic ISSN 1843-5386

DOI 10.15835/buasvmcn-agr: 002417

\begin{abstract}
Soybean yields could benefit from the use of improved varieties, nutrients and rhizobium inoculants. In this study we evaluated the influence of fertilization with liquid manure upon soybean yield in the 3rd experimental year, in climatic condition specific to the year 2016. The experiences were installed on Agricultural ResearchDevelopment Station Turda, on a chernozem soil. We followed the response of two soybean varieties to organic fertilization with liquid manure. In this regard we analyzed the number of nodules at the beginning and at the end of flowering and bean production. The results pointed out that in general Onix genotype recorded the highest values on bean production when $15 \mathrm{t} /$ ha liquid manure were applied.
\end{abstract}

Keywords: soybean, fertilization, year, doses, liquid manure.

\section{Introduction}

Soybean are leguminous plant and normally they provide their own nitrogen required for the plant growth and development through a symbiotic relationship with nitrogen-fixing bacteria Bradyrhizobium japonicum (Sarkodie-Addo et al., 2006; Nastasija et al., 2008). Bacteria present in soybean root lymph of fixing atmospheric nitrogen thus ensuring the plant necessary for this element (Darryl et al., 2004; Nastasija et al., 2008).

The growth and development of plants is important for successful adaptation of a species to its environment geographic and climatic. Adapting a species specific to a region growing season ensures species reproduction fund (Mureșanu et al., 1994). The annual species, the seed must germinate, grow, bloom, forming seeds and grow during the growing season, otherwise there is a risk of failure in the reproduction of plants.

The beneficial effect of the application of inorganic fertilizers on the plant height, leaf area index, dry matter production and grain yield of soybean is well documented (Ganesaraja, 1990; Abbas et al., 1994; Singh et al., 1995). Tagoe et al. (2008) developed a study to investigate the effects of nitrogen derived from dried or carbonized chicken manure on growth, nodulation, yield and $\mathrm{N}$ content of soybean and they pointed out that the application of carbonized chicken manure increased soybean seed yield by $23 \%$ and $43 \%$ for the 50 and $100 \mathrm{~kg} \mathrm{~N}$ ha-1 rates respectively. Also Adeli et al. (2005) highlighted that soybean grain yield and $\mathrm{N}$ uptake from broiler litter applications were significantly greater than those from commercial fertilizer.

ARDS Turda (Agricultural Research Development Station) deals with soybean research for a long time and the researchers develop several soybean varieties until present. Felix and Onix are among the most suitable varieties created on ARDS Turda but studies are still required to highlight the adequate technologies for achieving the ultimate goal of efficient productivity (high yields with minimum inputs of fertilizer). Thus a research 
Table 1. The influence of fertilization with liquid manure on the number of nodules at the beginning of flowering on Felix soybean variety

\begin{tabular}{ccccc}
\hline Variable & G1 & G2 & G3 & G4 \\
\hline G1 & & 0.714 & 0.675 & 0.718 \\
\hline G2 & 0.714 & & 0.501 & 0.443 \\
\hline G3 & 0.675 & 0.501 & 0.805 \\
\hline G4 & 0.718 & 0.443 & 0.805 & \\
\hline Note: G1 (control, unfertilized; 0 t/haliquid manure), G2 (fertilized with 5 t/haliquid manure), G3 (fertilized with 10 t/ha liquid manure),
\end{tabular}
G4 (fertilized with $15 \mathrm{t} /$ ha liquid manure).

Table 2. The influence of fertilization with liquid manure on the number of nodules at the beginning of flowering on Onix soybean variety

\begin{tabular}{ccccc}
\hline Variable & G1 & G2 & G3 & G4 \\
\hline G1 & & 0.925 & 0.797 & 0.825 \\
\hline G2 & 0.925 & & 0.651 & 0.873 \\
\hline G3 & 0.797 & 0.651 & & 0.560 \\
\hline G4 & 0.825 & 0.873 & 0.560 & \\
\hline
\end{tabular}

Note: G1 (control, unfertilized; $0 \mathrm{t} /$ ha liquid manure), G2 (fertilized with $5 \mathrm{t} /$ ha liquid manure), G3 (fertilized with 10 t/ha liquid manure), G4 (fertilized with $15 \mathrm{t} /$ ha liquid manure).

aimed to follow the influence of fertilization with liquid manure on the number of nodules at the beginning of flowering and bean production for two soybean varieties was carried out, having as ultimate goal to identify the most adequate fertilization plan for each soybean variety and also to point out which variety is the most productive.

\section{Materials and methods}

The research has been carried out on ARDS Turda, on a chernozem soil. Soil analysis revealed good supply in chemical elements and good soil fertility. The climatic indices for the year 2016 scored $550 \mathrm{~mm}$ rainfalls and an average temperature of $11,5^{\circ} \mathrm{C}$.

The research aimed to follow the influence of fertilization with liquid manure on the number of nodules at the beginning of flowering and bean production for two soybean varieties, namely Onix and Felix. The ultimate goal was to highlight the most adequate fertilization plan for each soybean variety and also to point out which variety is the most productive. We used the randomized blocks method, with 8 plots in 4 replicates. The experimental factors and their graduations are the doses of liquid manure with 4 graduations: G1 (control, unfertilized; 0 t/ha liquid manure), G2 (fertilized with 5 t/ha liquid manure), G3 (fertilized with $10 \mathrm{t} /$ ha liquid manure), and G4 (fertilized with $15 \mathrm{t}$ /ha liquid manure) and the genotype with 2 graduations: $F$ (Felix) and 0 (Onix). The liquid manure was provided from a cow farm located in the area of the experimental site. According to the chemical analyzes bulletin the liquid manure contained: N-NO - $1461 \mathrm{ppm}$, $\mathrm{N}-0,730 \mathrm{ppm}, \mathrm{P}-112 \mathrm{ppm}$ and $\mathrm{K}-3438 \mathrm{ppm}$. Statistical interpretation of data was performed with Statistica vs. 10.

\section{Results and discussions}

The results show a significant influence of fertilization with liquid manure on the number of nodules at the beginning of flowering for Felix variety. The most significant increase was recorded at G4, experimental plot fertilized with $15 \mathrm{t} / \mathrm{ha}$ liquid manure.

Significant increases were recorded also on the number of nodules at the beginning of flowering for Onix variety. The most significant increase was recorded at G2, experimental plot fertilized with 5 t/ha liquid manure.

Our results are confirmed by other researches in the field. Yamika and Ikawati (2012) pointed out in a study that liquid manure could give superior number of nodules compared to mineral fertilizers. Positive relationship between liquid manure fertilization and the number of nodules in soybean were reported also by Blum et al. (2003) and Carvalho et al. (2011).

The highest number of nodules at the beginning of flowering period was recorded on Felix variety (Fig. 1.), with a maximum number of 132 nodules. 


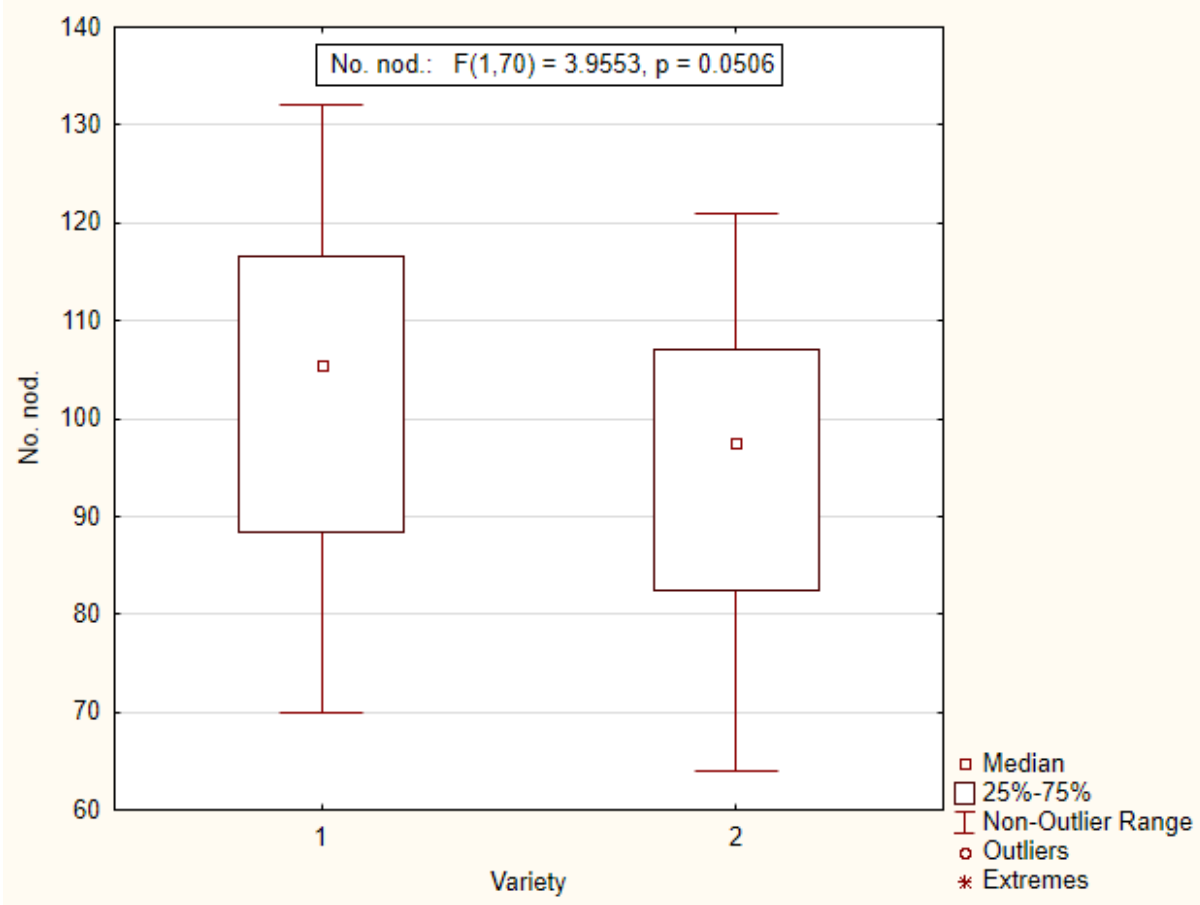

Figure 1. The influence of soybean variety on the number of nodules at the beginning of flowering Note: 1 - Felix variety; 2 - Onix variety; No.nod. - Number of nodules at the beginning of flowering.

Table 3. The influence of fertilization with liquid manure on bean production for Felix soybean variety

\begin{tabular}{ccccc}
\hline Variable & G1 & G2 & G3 & G4 \\
\hline G1 & & 0.434 & 0.293 & 0.465 \\
\hline G2 & 0.434 & & 0.575 & 0.657 \\
\hline G3 & 0.293 & 0.575 & & 0.619 \\
\hline G4 & 0.465 & 0.657 & 0.619 &
\end{tabular}

Note: G1 (control, unfertilized; $0 \mathrm{t} /$ ha liquid manure), G2 (fertilized with $5 \mathrm{t} /$ ha liquid manure), G3 (fertilized with $10 \mathrm{t} / \mathrm{ha}$ liquid manure), G4 (fertilized with $15 \mathrm{t} /$ ha liquid manure).

Table 4. The influence of fertilization with liquid manure on bean production for Onix soybean variety

\begin{tabular}{ccccc}
\hline Variable & G1 & G2 & G3 & G4 \\
\hline G1 & & 0.303 & 0.482 & 0.174 \\
\hline G2 & 0.303 & & 0.488 & 0.511 \\
\hline G3 & 0.482 & 0.488 & & 0.796 \\
\hline G4 & 0.174 & 0.511 & 0.796 & \\
\hline
\end{tabular}

Note: G1 (control, unfertilized; $0 \mathrm{t} /$ ha liquid manure), G2 (fertilized with $5 \mathrm{t} /$ ha liquid manure), G3 (fertilized with $10 \mathrm{t} / \mathrm{ha}$ liquid manure), G4 (fertilized with $15 \mathrm{t} / \mathrm{ha}$ liquid manure).

Analyzing the influence of treatment with liquid manure on bean production we observed that the increases were insignificant for Felix variety (Tab. 3.). The highest production were recorded on fertilization with 15 t/ha liquid manure.

For Onix variety the highest increase was recorded on G4, fertilized with $15 \mathrm{t} /$ ha liquid manure. The differences were significant from statistical point of view.
Similar reaction of new soybean hybrids to liquid manure application were reported also by Travaglia et al. (2010) and Maheshbabu et al. (2008). Raganin et al. (2012) pointed out that the positive response of bean production of soybean to liquid manure fertilization is due to the lack of mineral elements in soil such as $\mathrm{N}$ content.

In which concerns the influence of soybean variety on bean production we observed that the highest values were recorded for Onix variety 


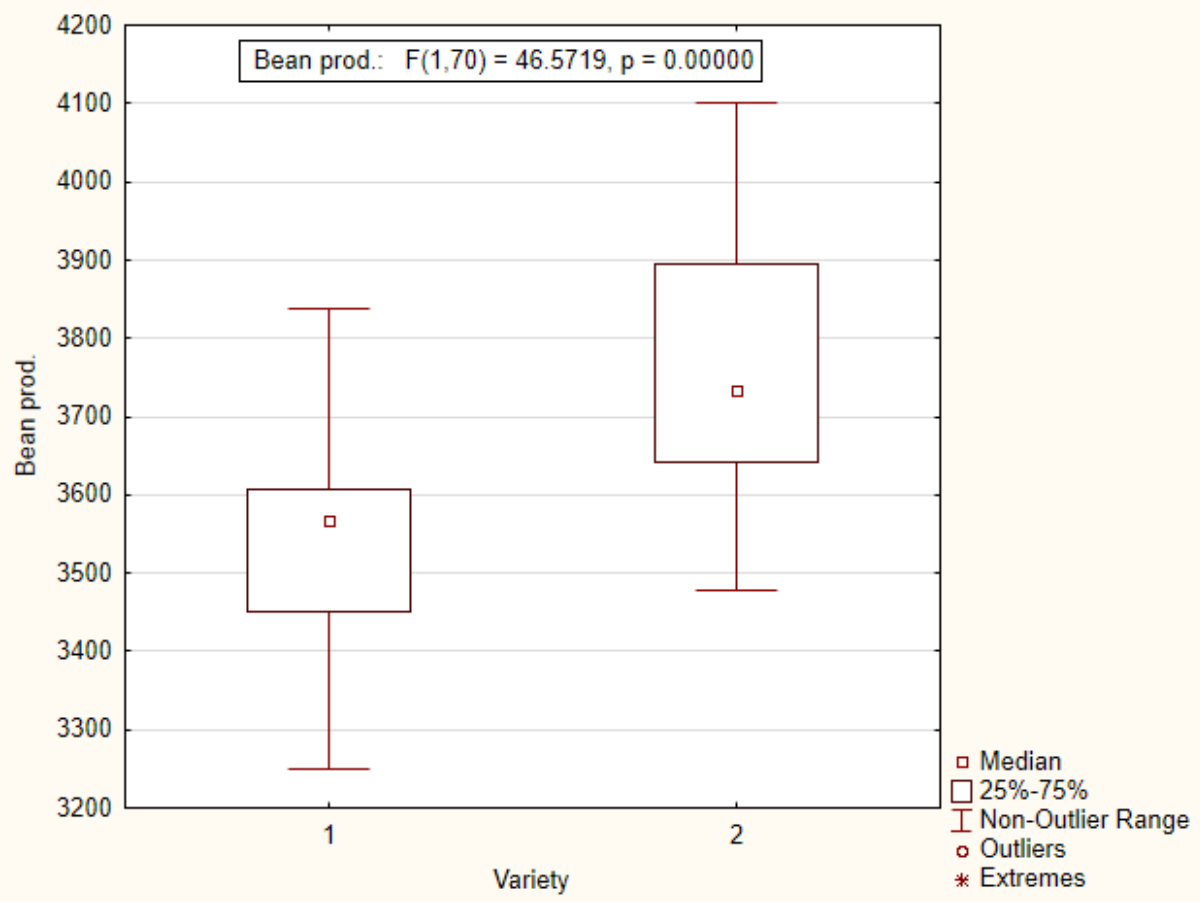

Figure 2. The influence of soybean variety on bean production Note: 1 - Felix variety; 2 - Onix variety; Bean prod. - bean production.

(Fig. 2). The results were very significant from statistical point of view.

The maximum bean production of $4101 \mathrm{~kg}$ was recorded on Onix variety, on fertilization with the maximum amount of liquid manure, $15 \mathrm{t} / \mathrm{ha}$ liquid manure. The minimum production of 3281 kg was recorded on Felix variety on control plot, unfertilized.

\section{Conclusion}

Despite its lower yields compared to Onix genotype, good production are given also by Felix in the soil-climatic condition specific to Transylvania Plain. Our research highlighted that the highest yields are achieved by Onix genotype. In which concerns the fertilization regime, treatment with $15 \mathrm{t} / \mathrm{ha}$ liquid manure is recommended since gave the highest bean production.

\section{References}

1. Abbas M, Singh MP, Nigam KB, Kandalkar VS (1994). Effect of phosphorus, plant densities and plant types on different growth and physiological parameters of soybean. Indian J. Agron. 39: 246-248.

2. Adeli A, Sistani KR, Rowe DE, Tewolde H (2005). Effects of broiler litter on soybean production and soil nitrogen and phosphorus concentration. Agron J 97:314-321.

3. Blum LEB et al. (2003). Produção de moranga e pepino emsolo com incorporação de cama aviária e casca de pinus. Horticultura Brasileira, Brasília, 21 (4): 627-631.
4. Carvalho ER et al., (2011). Fertilizante mineral e resíduo orgânico sobre características agronômicas da soja e nutrientes no solo. Revista Ciência Agronômica, Fortaleza, 42(4): 930-939.

5. Darryl W, Dahl J, Jacobs L, Laboski C (2004). Nutrient Recommendation for Field Crops. Extention Bulletin E2904. Michigan State Univ., 32.

6. Ganesaraja V (1990). Yield maximization studies in soybean with plant density, growth retardant and fertilizer nutrients. M.Sc.(Ag) Thesis, Tamil Nadu Agric. Univ., Coimbatore.

7. Nastasija M, Jelena M, Acimovic R (2008). Effect of nitrogen fertilizer application on growth and yield inoculate. Agrobot. C/UJ 36 (1): 48-51.

8. Maheshbabu HM, Hunje R, Patil NK (2008). Effect of organic manures on plant growth, seed yield and quality of soybean. Karnataka J. Agric. Sci. 21(2): 219-221.

9. Mureşanu E, Cătinas Leontina (1994). Realizations and perspectives in soybean on ARDS Turda. Contribtions of scientific research on agriculture development, 5: 161174.

10. Ragagnin VA, De Sena Jr. DG, Dias DS, Braga WF, Moraes Nogueira PD, Kumudini S (2010). Soybean growth and development. In: The soybean, botany, production and uses, India, Editura CAB Internaional.

11. Sarkodie-Addo J, Adu-Dapaah HK, Ewusi-Mensah N, Asare E (2006). Evaluation of medium maturing soybean lines for their nitrogen fixation potentials. Journal of Science and Technology, 26(2): 34-39.

12. Singh A, Awasthi RP, Singh RD (1995). Effect of fertilizers, manure and lime on soybean (Glycine max) grown in mid hills at Sikkim. Indian J. Agron. 40: 613-615.

13. Tagoe SO, Takatsugu H, Tsutomu M (2008). Effects of carbonized and dried chicken manures on the growth, 
yield, and N content of soybean. Plant and Soil, 306(1-2): 211-220.

14. Travaglia C, Reinoso H, Cohen A, Luna C, Tommasino E, Castillo C, Bottini R (2010). Exogenous ABA increases yield in fieldgrown wheat with Moderate water restriction.
Journal of Plant Growth Regulation DOI 10.1007/s00344010-9147-y, ISSN 07217595, pg. 88.

15. Yamika WSD, Ikawati KR (2012). Combination inorganic and organic fertilizer increased yield production of soybean. American-Eurasian J. Sustainable Agric. 6(1): 14-17. 